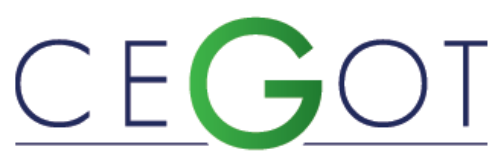

Centro de Estudos de Geografia e Ordenamento do Território
Pinho, Giselle Fernandes

Doutora em Arquitetura e Urbanismo pelo PPGATC - UNICAMP

66635-110, Belém, Brasil

fpgiselle@gmail.com

OliveIRA, KAMILA DINIZ

Mestre em Arquitetura e Urbanismo pelo PPGAU - UFPA

66075-110, Belém, Brasil

kamiladinizoliveira@gmail.com

Cardoso, Ana Cláudia Duarte

Doutora em Arquitetura e Urbanismo, Professora da Faculdade de

Arquitetura e Urbanismo da UFPA e do PPGAU - UFPA

66075-110, Belém, Brasil

aclaudiacardoso@gmail.com

\title{
ENTRE O VERNACULAR E O TÉCNICO - ANÁLISE DA FORMA DE VILAS RURAIS NA REGIÃO TOCANTINA
}

\author{
BETWEEN THE VERNACULAR AND THE TECHNICAL - AN ANALYSIS OF THE FORM OF RURAL VILLAGES IN THE
} TOCANTINS RIVER REGION

Referência: Pinho, Giselle Fernandes; Oliveira, Kamila Diniz; Cardoso, Ana Cláudia Duarte (2021). ENTRE O VERNACULAR E O TÉCNICO - ANÁLISE DA FORMA DE VILAS RURAIS NA REGIÃO TOCANTINA. Revista de Geografia e Ordenamento do Território (GOT), no 22 (Dezembro). Centro de Estudos de Geografia e Ordenamento do Território, p. 83 - 110, dx.doi.org/10.17127/got/2021.22.004

\section{RESUMO}

Na região amazônica coexistem dois tipos de ocupação humana, um tradicional, referente à rede urbana dendrítica, e outro implantado pós-1960, ligado à implantação de rodovias. Este artigo objetiva comparar os padrões de ocupação de vilas formadas no âmbito das duas categorias, em busca de suas similaridades e dissonâncias, para dizer quais e o quão relevantes são as diferenças morfológicas existentes entre as vilas tradicionais e as formadas após 1960. Oito vilas foram investigadas, localizadas em três municípios do nordeste do Estado do Pará, Brasil (Moju, Cametá e Mocajuba). A comparação baseou-se em análise morfológica seguindo critérios relacionados aos parâmetros da forma (características internas aos assentamentos), da escala (características microrregionais) e do tempo (ação dos agentes e políticas públicas). Após análise dos critérios sistematizados em croquis e tabelas comparativas, conclui-se que a forma introduzida após 1960 utiliza o tipo tradicional como base, acrescendo-lhe contribuições oriundas das cidades, enquanto intervenções estandardizadas no tipo tradicional aceleram mudanças no modo de vida de seus habitantes. O Parâmetro Forma revela as principais diferenças espaciais, o Parâmetro Escala aponta os padrões econômico-sociais, e o Parâmetro Tempo indica os desafios futuros para que haja melhora da qualidade de vida e cidadania nas vilas da região estudada. 
Palavras-chave: Morfologia urbana, Amazônia Oriental, vilas rurais, vilas tradicionais, políticas públicas.

\begin{abstract}
Two types of human occupation coexist in the Amazon region, one traditional, referring to the dendritic urban network, and the other implanted post-1960, linked to the implementation of highways. This paper aims to compare the occupation patterns of villages formed within the scope of the two categories, in search of their similarities and dissonances, to say which and how relevant are the morphological differences existing between the traditional villages and those formed after 1960. Eight villages were investigated, located in three municipalities in the northeast of Pará State, Brazil (Moju, Cametá and Mocajuba). The comparison was based on morphological analysis following criteria related to the parameters of spatial form (internal characteristics of the settlements), scale (micro-regional characteristics) and time (actio of agents and public policies). After analysis of the criteria systematized in sketches and comparative tables, it is concluded that the form introduced after 1960 uses the traditional type as a basis, adding to it references coming from the cities, while standardised interventions in the traditional type accelerate changes in the way of life of its inhabitants. The form parameter reveals the main spatial differences, the scale parameter points out the economic and social patterns, and the time parameter indicates the future challenges for improving the quality of life and citizenship in the villages of the region studied.
\end{abstract}

Keywords: Urban morphology, Eastern Amazon, rural village, traditional village, public policies.

\title{
1. Introdução
}

Este texto analisa um tipo de assentamento humano que é base urbana para população que vive em meio rural amazônico - as vilas ${ }^{1}$, em busca de diferenças entre as vilas seculares e aquelas de criação recente e, principalmente, de elementos que possam apoiar políticas e planos de desenvolvimento destinados a estes contextos, que por falta de registros, desconsideram que tal base urbana seja o suporte para a melhoria da qualidade de vida de populações inseridas em áreas rurais. Some-se a isso, o fato de que a contínua influência do

\footnotetext{
${ }^{1}$ No Brasil, o Decreto-Lei n.o 311, de 1938 definiu que são cidades todas as sedes municipais, independente da extensão do município ou da quantidade de habitantes. A cidade é o distrito sede; além deste os municípios podem ser divididos em outros distritos, que podem ter uma vila, como sede distrital. $O$ temor de pedidos de subdivisão municipal faz com que muitos municípios não promovam a organização do território municipal em distritos, nem informem oficialmente a administração federal sobre a existência de vilas. Na sub-região deste estudo o município de Cametá, por exemplo, criado no século XVII conta com mais de 500 localidades, dentre as quais destacam-se uma dezena de vilas com vários bairros e demandas por equipamentos e serviços análogos aos existentes nos bairros das cidades. Na Amazônia a população rural representa pelo menos o dobro da média brasileira (cerca de 15\% do total) (IBGE, 2012), e embora trabalhe a terra habita as vilas.
} 
modo de vida urbano já promoveu a gênese de cidades a partir das vilas, nos processos de subdivisão administrativa em muitas sub-regiões do estado do Pará, segundo maior estado da Amazônia Brasileira.

Assentamentos análogos às vilas existem desde a Amazônia pré-cabralina, que contou com uma urbanização própria, constituída por acoplamentos humano-ambientais, que se organizavam de forma dispersa, mas articulada, com gradientes de intensidade de ocupação e usos do solo variáveis entre rios e floresta (HECKENBERGER et al, 2008). Após um século de ações militares, apenas nos séculos XVII e XVIII a política colonial portuguesa adotou a urbanização e a ocupação civil como estratégia prioritária, mantendo a matriz indígena de ocupação das margens dos principais cursos d'água, para vencer a disputa pelo domínio da região com outras nações colonizadoras europeias.

Contudo, houve um longo percurso até este ponto; a análise de mapas e registros históricos indica três padrões de ocupação do território pelo colonizador: (1) a ocupação militar por povoações fortificadas (BAENA, 1969); (2) a ocupação religiosa, por meio de missões e aldeamentos, do tipo mais extensiva, visto que as principais ordens religiosas receberam jurisdição sobre diversas bacias hidrográficas e respeitavam as formas de ocupação indígenas (CHAMBOULEYRON, 2010, TAVARES 2011); e (3) a ocupação civil que refere-se à divisão territorial em capitanias privadas e sua subdivisão em sesmarias.

Observe-se que as bases econômicas da urbanização colonial foram a pecuária, a agricultura e o extrativismo de madeira e drogas do sertão (MIRANDA, 2009), viabilizados pela apropriação do saber e pela escravidão indígena (MARIN, 2009). Apesar das regras originais para a implantação formal de uma capitania preverem a criação de vilas, erigidas pelo donatário, que deveriam ser sustentadas pela agricultura, única forma de caracterizar a apropriação do território perante a coroa espanhola (CHAMBOULEYRON, 2010), foi o extrativismo dos produtos prontos da floresta que se mostrou mais promissor economicamente, e baseado no conhecimento local, deu longevidade aos padrões espaciais e práticas tradicionais (COSTA, 2020).

Os assentamentos que foram gerados entre o século XVII e a primeira metade do século XX formaram uma rede urbana macrocéfala, em que uma cidade primaz concentra a maior parte do comércio interno e externo, gerando uma hinterlândia de pequenos núcleos 
indiferenciados entre si, com baixa demanda comercial, dependentes da cidade primaz para transações comerciais que lhe favoreciam o crescimento, ao mesmo tempo que causavam a estagnação de sua hinterlândia (CORREA, 1988). Esse tipo de formação manteve-se por mais de três séculos, e neste sentido é chamado de tradicional. Só foi alterado após 1960, quando a implantação de rodovias criou um novo padrão de ocupação, em que novas formas de uso da terra e novos assentamentos humanos - comunidades e vilas, eventualmente transformadas em cidades por subdivisão municipal, foram criadas pelo governo (ver CAMARGO, 1973) e implantados pela população migrante de forma espontânea (CARDOSO, LIMA, 2006). Destes dois grupos de assentamentos gerados após 1960, interessam à pesquisa aqueles de ocupação espontânea para a investigação de paralelos entre os assentamentos antigos, herdeiras do conhecimento ancestral e que mantêm suas atividades cotidianas ligadas ao ritmo da natureza, e esses novos. Note-se que após a implantação de estradas, e da reestruturação do território por políticas governamentais, houve uma ampliação de níveis na rede urbana (IBGE, 2012), mas a rede constituída por cidades (que no Brasil são as sedes municipais) e as vilas, assentamentos humanos que aglutinam população no interior de extensos municípios amazônicos, ainda não é oficialmente reconhecida, em decorrência disso, embora as vilas de maior porte sejam constituídas como áreas urbanas (descontínuas em relação à cidade), não há políticas específicas para estes assentamentos isolados em geral. A falta de formalização e registro por parte dos municípios ora impede o atendimento de sua população, ora faz com que recebam intervenções baseadas em parâmetros adotados nas capitais estaduais e metrópoles, maiores cidades brasileiras.

Diante deste impasse, este artigo investiga quais e o quão relevantes são as diferenças morfológicas entre vilas históricas e contemporâneas, por meio da comparação de seus atributos morfológicos. Busca-se tanto a identificação de similaridades e dissonâncias entre oito vilas localizadas em três municípios do nordeste do Estado do Pará (Moju, Cametá e Mocajuba), quanto à produção de evidências sobre a assimilação de características contemporâneas pelas comunidades tradicionais e vice-versa. Espera-se contribuir para o entendimento de como a população que é vista como rural, mas que efetivamente vive em vilas, ou em níveis de aglomerados rurais, se organiza no espaço e como ela se utiliza de referências e usos típicos das cidades; e também para o registro do conhecimento autóctone 
e o balizamento de intervenções de produção habitacional e de provisão de infraestrutura nestes contextos.

\section{A gênese das vilas e assentamentos rurais tradicionais e pós anos}

\section{0}

Os assentamentos de matriz tradicional aglutinam heranças dos povos formadores da região Amazônica (indígenas, portugueses e africanos), resultando em uma ocupação de caráter coletivo nucleada por uma igreja matriz e um terreiro aberto para circulação e reunião. A convivência de 300 anos de três vertentes culturais sob condições históricas muito peculiares levou à profunda hibridação étnica, que se constituiu num substrato híbrido (WEIMER, 2012) que caracteriza as vilas das comunidades mais antigas.

Esta hibridação começava com a entrada das ordens religiosas nos aldeamentos indígenas para iniciar a catequese, que era seguida pela adaptação destes espaços, a partir da construção de um cruzeiro no meio do terreiro. Depois os missionários erigiam uma capela na frente do cruzeiro ou em substituição a alguma casa. Gradativamente, algumas casas eram aglutinadas para que uma igreja surgisse e dominasse o espaço. Desse modo foi iniciada a integração entre indígenas e colonizadores nas vilas, surgidas no lugar das aldeias, com duas mutações: a introdução da igreja no centro do terreiro e a construção das casas dos colonizadores, identificadas pelos quintais e materiais de construção - pedra, tijolos, argamassa e madeira (WEIMER, 2012). Com a progressiva chegada de colonizadores, essas vilas foram expandidas por meio da abertura de novas ruas, ao longo das trilhas abertas pelos indígenas. A igreja localizada em um lado da praça que substituiu o antigo terreiro tornou-se marco da interação das culturas indígena e portuguesa (WEIMER, 2012).

Indígenas e Africanos escravizados, fugidos das missões e escondidos na floresta protagonizaram em outra vertente de ocupação da região, como agentes da formação de diversas aldeias e quilombos. Estes atores sociais geraram diversas comunidades tradicionais assentadas que persistem até o presente (MALHEIRO, TRINDADE JÚNIOR, 2010).

As culturas indígena e africana apresentavam construções simples, integralmente produzidas com materiais vegetais e terra, não utilizavam cercamento, por não conhecerem a propriedade privada do solo, e definiam o espaço de convívio como área de domínio 
feminino. Todas as atividades desses povos respeitavam a execução das atividades conforme o gênero. Outra herança dos povos indígenas para as comunidades tradicionais ${ }^{2}$ foi a transmissão do manejo e cultivo da mandioca, dos tipos brava e mansa, e da respectiva produção da farinha, principais atividades nas roças das comunidades tradicionais localizadas na terra firme. Considerada a mais brasileira das culturas agrícolas, por ter origem atribuída ao Brasil, e ser cultivada em todo o país (Embrapa, 2010, 30,46). O cultivo da mandioca até hoje tem território específico afastado das residências, rios e do local de criação de animais (devido à toxicidade de suas raízes), porém próximo a um equipamento chamado "casa de farinha".

Por outro lado, a partir da década de 1960, com a implantação de rodovias federais e estaduais, ampliou-se na Amazônia Ocidental a implantação de pequenos povoados e vilas por população migrante em busca de terras, gerando uma mão de obra volante e intensificando o que Hébette e Acevedo (1979) chamam de baixo terciário, ou seja, prestação de serviços que em sua maioria são informais.

Os planos governamentais das décadas de 1970 e 1980, criaram novas vilas que reproduziam em pequena escala um bairro das cidades da região, apesar do modo de vida rural. Isso significava uma preocupação com parcelamento da terra, sistema de ruas e distribuição de usos e equipamentos, que seguiam uma concepção técnica, que foi introduzida por meio dos projetos de assentamento do Instituto Nacional de Colonização e Reforma Agrária (INCRA, autarquia criada para a promoção do desenvolvimento rural, subordinado ao Ministério da Agricultura), chamada de Urbanismo Rural, e desenvolvida pelo arquiteto José Geraldo da Cunha Camargo (CAMARGO, 1973) que defendia a residência do rurícola em pequenos núcleos urbanos inseridos no meio rural, para facilitar a socialização e a satisfação de necessidades básicas.

O Urbanismo Rural ignorava os padrões de ocupação tradicionais, e propunha a implantação de uma hierarquia de três tipos de núcleos urbanos, ao longo da Rodovia Transamazônica,

\footnotetext{
${ }^{2}$ Grupos culturalmente diferenciados e que se reconhecem como tais, que possuem formas próprias de organização social, que ocupam e usam territórios e recursos naturais como condição para sua reprodução cultural, social, religiosa, ancestral e econômica, utilizando conhecimentos, inovações e práticas gerados e transmitidos pela tradição. Esses grupos ocupam e usam, de forma permanente ou temporária, territórios tradicionais e recursos naturais como condição para sua reprodução cultural, social, religiosa, ancestral e econômica (Decreto no 6.040, 2007).
} 
conhecido como "Sistema de Agrovilas". Cada nível da hierarquia possuía uma quantidade maior de serviços, equipamentos e complexidade morfológica no qual as "Agrovilas" polarizariam um raio de ação de $7 \mathrm{~km}$, servindo um conjunto de lotes rurais; as "Agrópolis" atenderiam a um conjunto de 22 Agrovilas, posicionadas a cada $40 \mathrm{~km}$ da rodovia: e por fim as "Rurópolis" seriam pontos de integração microrregional, posicionadas a cada $140 \mathrm{~km}$ da rodovia (INCRA, 1971, CAMARGO, 1973).

O Urbanismo Rural previa a implantação de um sistema de duplo loteamento: rural e urbano. No assentamento urbano, a malha viária fechada era composta segundo o sistema Rua-LoteQuadra, conjunto de equipamentos e serviços urbanos de baixa complexidade, como escola e posto de saúde (INCRA, 1971, CAMARGO, 1973). Apesar de esta proposta ser vinculada à política de ocupação implementada pelo Governo Federal para assentamento da migração induzida para a região, não houve recursos para a sua completa efetivação. Após o loteamento rural, os próprios assentados improvisaram as vilas nos pontos em que elas eram previstas, enquanto populações migrantes não contempladas pelo sistema oficial ocupavam terras públicas como áreas de produção e improvisavam suas vilas, seguindo a mesma lógica de articulação de vilas a loteamentos rurais que foi introduzida pelo INCRA. Houve uma absorção e adaptação da técnica de produção de parcelamento, produção de malha viária e introdução de usos de apoio à habitação, que resultou em ocupações menos geométricas, que segundo Hébette, Alves e Quintela (2002) ocorria em agrupamentos, porém seguindo normas próprias que levavam em consideração as necessidades das famílias e a proximidade a uma fonte de água.

Esse padrão de ocupação também não seguiu rigorosamente a malha viária fechada. Segundo estes autores, foram constituídos dois tipos básicos: os "aglomerados-rua" e os "aglomerados-agrupados". Estes tipos indicam o posicionamento das edificações em um sistema viário linear ou de grelha, e por outro lado apontam para uma hierarquização, semelhante àquela do Sistema de Agrovilas, baseada no oferecimento de serviços aos habitantes. Segundo os autores havia pelo menos três níveis hierárquicos: "aglomerados de uma ou duas dezenas de casas, com sua igreja ou seu templo rústico, sua escola, seu lugar de reunião ou uma construção de uso diversificado, que faz as vezes dele" que corresponde ao que o IBGE assume como um "Lugar"; "(...) um povoado com sua escola, seu comércio, seu bar, oficinas de artesãos " $\mathrm{e}$ "(...) centros maiores, tipicamente comerciais, possivelmente com 
uma escola secundária, um pequeno posto de saúde, algumas farmácias, um posto de polícia, e, é claro, um padre e pastores" ambos os níveis fazendo referência ao que o IBGE considera um "povoado", mas com um caráter diferenciado pela própria hierarquia dos serviços ofertados (HÉBETTE, ALVES, QUINTELA, 2002, P.185; IBGE, 2014)

Na prática, este tipo de ocupação improvisada, mas fortemente influenciada pela concepção do INCRA sobrepôs padrões espaciais "rurais" e "urbanos". De um lado, a organização em escala regional era estruturada por rodovias, que formavam um tecido urbano estendido 3 (MONTE-MÓR, 1994), e permitiam que novos usos e escalas de produção (como a mineração ou agronegócio) dominassem o espaço de uma forma difusa, ideológica e comportamental, disputando territórios que no nível local e no âmbito da vida cotidiana mantinham o caráter rural ou tradicional. Gradativamente, os atores foram inseridos em uma lógica de consumo influenciada pela cidade, mas permaneciam produzindo e vivenciando as suas territorialidades localmente (RUA, 2006).

Houve uma ressignificação destas áreas rurais como parte de um território híbrido, "[...] não é um urbano ruralizado, nem um rural urbanizado" (RUA, 2006, p. 95), mas, sim, um local onde os componentes "rurais" e "urbanos" são usados "[...] estrategicamente, como discurso e reivindicações predominantes, de acordo com o momento vivido pelos agentes sociais locais, em situações de inferiorização (frente aos urbanos) e de reivindicações de direitos" (RUA, 2006, p. 95).

O capitalismo foi a força motriz de uma ressignificação do rural por meio da inserção incompleta dos pequenos produtores em estratégias urbano-industriais, tais como os consórcios com agroindústrias, ou o crédito bancário internacional que fomenta sustentabilidade, ou mesmo pela difusão tecnológica e pelo trabalho industrializado no campo, reconstituindo o espaço rural "em termos materiais e imateriais/simbólicos" em que

\footnotetext{
${ }^{3}$ Urbanização extensiva fenômeno levado por meio do tecido urbano que extrapola a cidade e sobrepõe, no território, as condições de produção industrial capitalista (mercado de trabalho, infraestrutura, energia, serviços sociais, comunicação e transportes, reprodução coletiva da força de trabalho, etc.) a virtualmente todo o espaço social, fortalecendo e enfatizando a integração sócio espacial, urbano-rural. Tal processo leva, de um lado, à redefinição e ampliação das possibilidades de localização das atividades econômicas, e, de outro, promove uma ampla integração entre o urbano e o rural e entre concentrações urbanas, gerando microssistemas urbanorurais onde centros e espaços periféricos se articulam funcionalmente ganhando dimensões e intensidades antes impensadas (MONTE-MÓR, 1994).
} 
as estruturas e suportes materiais antigos "são destruídos ou refuncionalizados para viabilizar reterritorializações permanentemente refeitas" (RUA, 2006, p. 96).

Desse modo, a ocupação rural pós 1960 tanto apresenta uma configuração de assentamento rural que expressa práticas de subsistência rurais (roçado, caça, pesca e extrativismo) quanto conta com uma organização espacial nas vilas, que são portadores de atributos de urbanidade - apropriação social do espaço, em diálogo com o espaço público, conforme Netto (2012) e Aguiar (2012), ou seja, a urbanidade criada a partir das infraestruturas e serviços - onde um conjunto de formas materiais e imateriais sintetizam a hibridação entre os universos rural e urbano, no qual o urbano está presente sem que o rural desapareça e o rural reveste-se de qualificações antes atribuídas exclusivamente às cidades (RUA, 2006, 2015). Para RUA (2012:398) as manifestações materiais da urbanidade estão ligadas ao acesso à infraestrutura e aos meios de comunicação, ou a novas formas de lazer, ocorrência de segunda residência, ao uso de antenas parabólicas e acesso à informação, ou ao turismo, à presença de indústrias em áreas rurais, ao uso de bens de consumo coletivo, ocorrência de especulação imobiliária por elevação do preço da terra, de novas relações de trabalho, ou de direitos trabalhistas como a aposentadoria Rural. Também está ligado a aspectos simbólicos e a hábitos difundidos pelas mídias, pela moda, individualização e preocupação com a segurança entre outros.

\section{A metodologia para a análise morfológica}

A morfologia urbana é um campo de conhecimento que estuda a evolução de cidades desde sua formação, ao identificar e dissecar seus vários componentes (MOUDON, 1997). Uma vez que toda forma urbana deriva de decisões tomadas por indivíduos e grupos, os estudos morfológicos também permitem identificar os agentes e as decisões que as modificam (LARKHAN, 2019). Este campo de conhecimento possui diferentes concepções de análise e dentre estas, as mais difundidas e conhecidas, são as escolas de morfologia italiana, inglesa e francesa, (WHITEHAND, 2013, MOUDON, 1997, LARKHAN, 2019), que seguem três parâmetros ou variáveis fundamentais de análise: forma, escala e tempo (MOUDON, 1997).

Segundo Moudon (1997), a forma de um assentamento está relacionada a três elementos físicos: as edificações, os lotes e as vias. O parâmetro escala é comumente relacionado a 
quatro níveis que correspondem à relação edifício/lote, à relação vias/quadras, à cidade, e à região. O parâmetro tempo diz respeito aos estudos históricos sobre transformações e alterações completas ou parciais destes elementos físicos nas suas diversas escalas de análise.

Visto que o escopo deste estudo é a configuração de vilas inseridas em contexto rural, bastante diverso daquele que originou tais escolas, reconheceu-se a necessidade de mediação das estratégias de análise morfológica. A pesquisa associou elementos básicos das escolas citadas, para registrar e discriminar as estruturas físicas e associá-las aos agentes que as produziram e às políticas públicas dirigidas para a região, de acordo com o esquema do quadro 1.

Quadro 1 - Elementos básicos para a análise

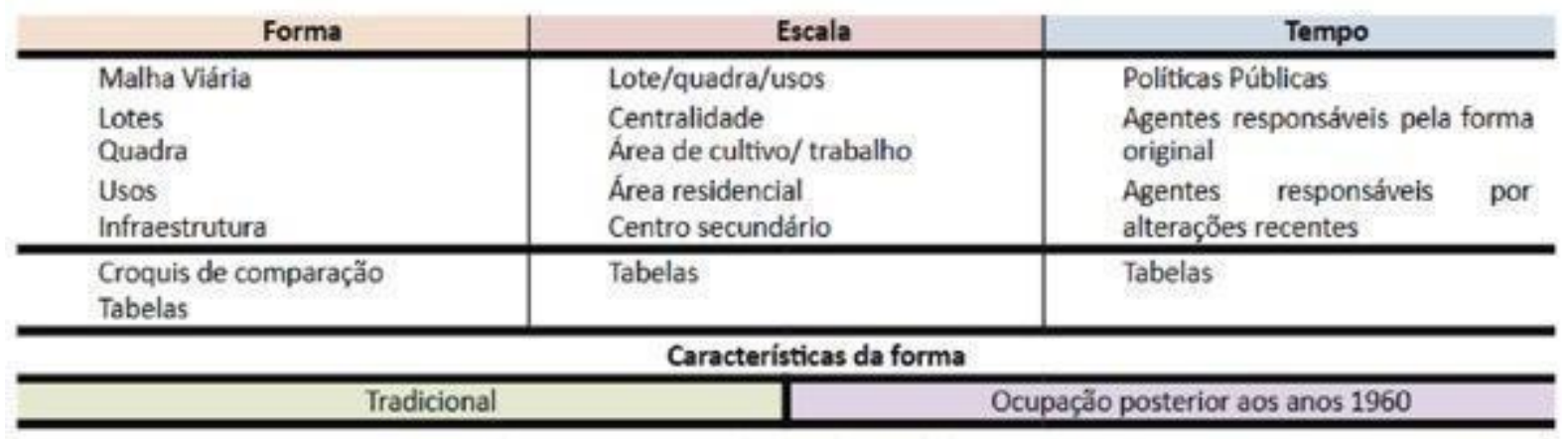

Para o Parâmetro Forma foram analisados (1) a malha viária (Tipo de tecido), (2) a demarcação de lote (quando aplicável), (3) a áreas de uso coletivo (formação de quadra quando aplicável), (4) usos das edificações e infraestrutura, a saber: Água, Eletricidade, Telefonia (antena), Resíduos Sólidos, Escola e seu nível de ensino e Posto de saúde). Para o Parâmetro Escala foram adotados os seguintes atributos: (1) composição dos centros da comunidade (ponto comercial de maior destaque, porte de comércio, tipo de atendimento), (2) extensão da área residencial, (3) área de cultivo/trabalho, e (4) centralidade secundária (quando aplicável). Por fim, para o parâmetro tempo foram identificadas as políticas públicas relacionadas à configuração original das comunidades, em paralelo à identificação dos agentes que as produziram e aqueles responsáveis por mudanças recentes, assim como os impactos de suas decisões. 


\section{Campo de observação: a Região Tocantina}

Se até a segunda metade do século XX prevalecia o padrão de dispersão de pequenas aglomerações no território fortemente ligada à logística dos rios. Contudo, uma nova racionalidade foi superposta àquela herdada de outros períodos, após a implantação de rodovias federais e estaduais, de projetos de assentamento rural, do projeto mineral Grande Carajás, composto pela implantação da usina hidrelétrica de Tucuruí, parques industriais para beneficiamento de minério e por minas de exploração industrial. Grande volume de migrantes foi direcionado para as frentes de obras logísticas, desencadeando transformações do meio natural e social existente.

Atualmente a rede urbana paraense articula a Região Metropolitana de Belém a algumas cidades médias e diversas cidades pequenas, sedes de municípios com níveis de população rural entre 30 e $70 \%$. Como já citado, esta rede também engloba vilas, localizadas nas áreas rurais de seus municípios, como as que são estudadas neste artigo, que mesmo inseridas em área rural, contam com configurações e infraestruturas passíveis de análise pela morfologia urbana. A figura 1 apresenta a ocupação contemporânea no estado do Pará, identificando a capital Belém (ponto amarelo), as demais cidades (sedes municipais, em verde) e a miríade de localidades e comunidades (pontos azuis), aqui reconhecidas como vilas de diferentes tamanhos.

A colonização portuguesa do território Amazônico foi iniciada pelo nordeste do estado do Pará, a partir de Belém, e seguida pela ocupação das áreas sob influência do Rio Tocantins. A Região Tocantina deixou de ser institucionalizada, mas ainda conta com forte identidade cultural e produtiva (extrativista e rural), e $52,8 \%$ da população vivendo fora das cidades (IBGE, 2012). Abrange uma área de $36.024,20 \mathrm{Km}^{2}$, que contém as bacias dos rios Moju, Pará e Tocantins, e onze municípios: Abaetetuba, Acará, Baião, Barcarena, Cametá, Igarapé-Miri, Limoeiro do Ajuru, Mocajuba, Moju, Oeiras do Pará e Tailândia. 


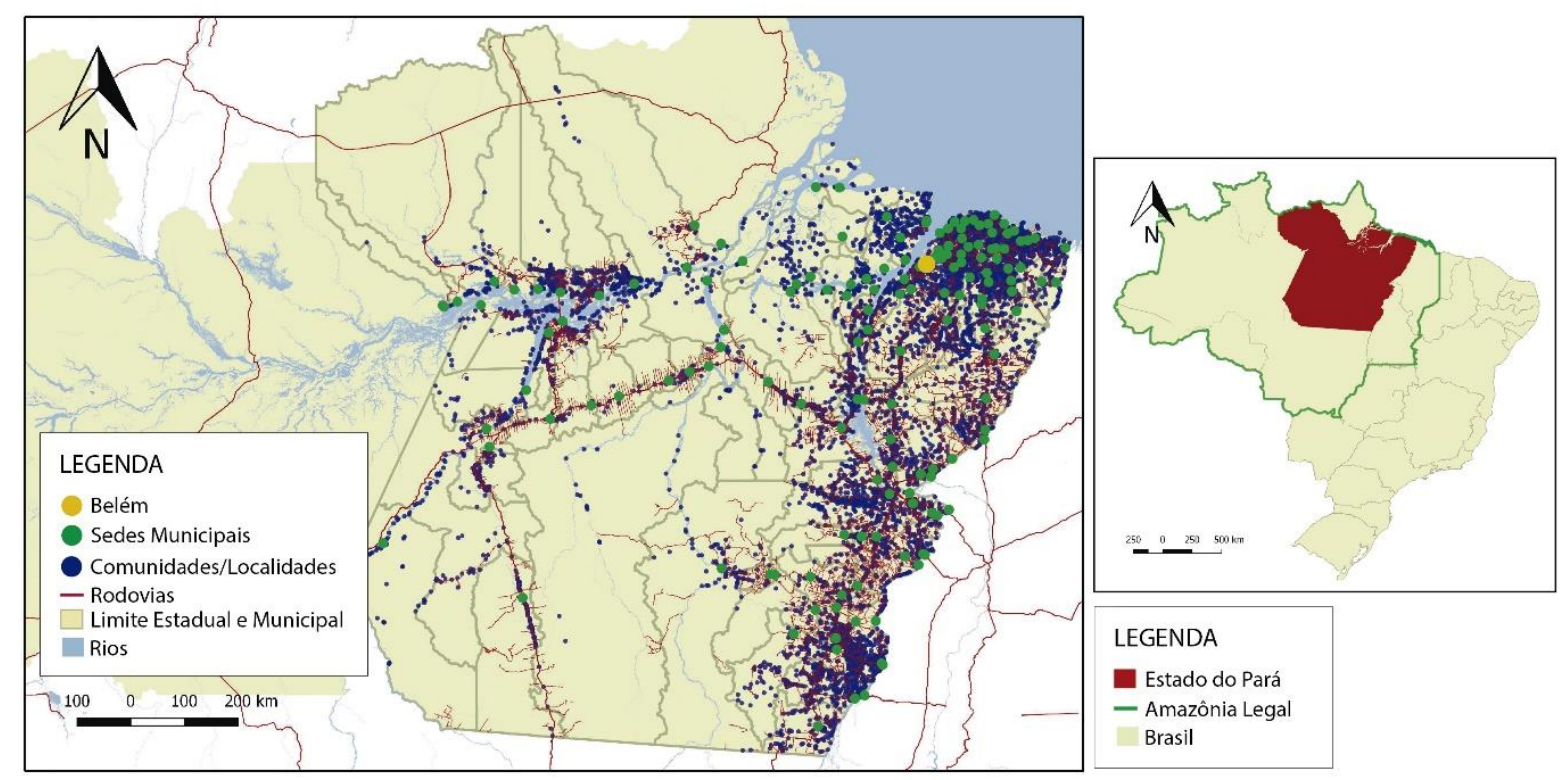

Figura 1 - Rede urbana, tipos e distribuição de assentamentos humanos no estado do Pará. As áreas que não são densamente ocupadas correspondem às áreas protegidas, onde predomina a floresta.

Elaboração: autores.

Nesta região o papel desempenhado pelos rios tem importância histórica para o transporte de mercadorias e pessoas. Nos municípios antigos a mobilidade originalmente era estritamente fluvial, o que gerou um padrão de ocupação denominado por Porto-Gonçalves (2005) de rio-várzea-floresta. A partir da década de 1970, este mesmo autor analisou o novo padrão de ocupação induzido pelas políticas federais, denominando-o estrada-terra firmesubsolo.

A construção da Usina Hidrelétrica de Tucuruí, a $380 \mathrm{~km}$ a sudoeste de Belém, promoveu o melhoramento e pavimentação de rodovias estaduais, referidas por PA-150, PA-151 e a Transcametá (PA-156). Em 2011, foi inaugurado o "Complexo Alça Viária", com pontes que possibilitaram a integração rodoviária da foz do Rio Tocantins, com a Região Metropolitana de Belém (RMB) e o sul e sudeste do Pará. A partir daí, um novo padrão de organização social do espaço geográfico foi estruturado pelas rodovias. Em função desta formação, a região possui vilas com características tanto do tipo morfológico tradicional quanto do tipo surgido pós-1960. Nesse sentido, foram selecionadas oito vilas para investigação (FIG. 2). 


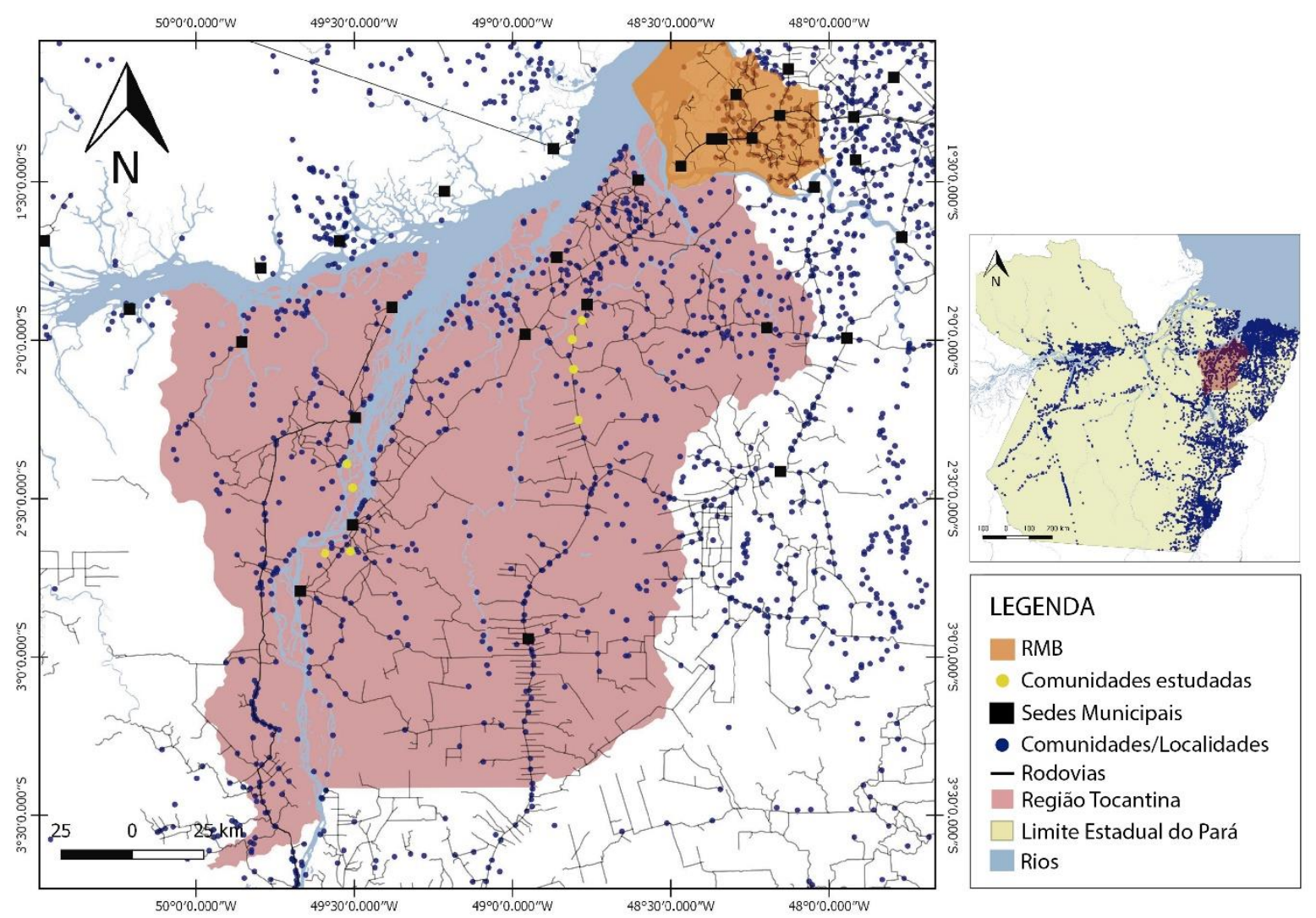

Figura 2 - Localização das comunidades estudadas.

Elaboração: Autoras

As quatro vilas, que representam aquelas constituídas após-1960 são: (1) Sucuriju, o menor aglomerado registrado na PA 150, localizado no trecho que atravessa o município de Moju, onde há a menor quantidade de serviços e equipamentos públicos; (2) Ateua Grande, vila de uma comunidade rural majoritariamente residencial, que tem área central relativamente compacta, com raio de extensão de 1,2 km; (3) Santa Maria, vila desmembrada em 2012 da vila do Trevo, por ocasião do registro de terras doadas por Manoel Firmo de Souza à associação de moradores; e (4) Olho D'água, vila originada de Assentamento Rural do INCRA, é a mais extensa e que possui maior quantidade de referências urbanas.

As vilas tradicionais selecionadas são: (1) Furtados, localizada na várzea do rio Tocantins, a 12,2 Km de distância da sede municipal de Mocajuba. A comunidade faz parte do Projeto de Assentamento Agroextrativista denominado de Ilha Grande Cametá e é habitada por 92 famílias, (2) Mutuacá de Baixo, localizada nas várzeas do rio Tocantins, a 15,5 km de distância da sede do município de Cametá e habitado por 86 famílias, (3) Cantanzal, vila ligada a um assentamento rural tradicional amazônico não protegido legalmente, habitada por 35 
famílias, e localizada no ramal de acesso à rodovia PA-151, (4) São José de Icatú, vila de uma comunidade remanescente de quilombo, fundada por volta de 1700 e habitada por 85 famílias que vivem da agricultura familiar, da pesca e do extrativismo, localizada no ramal do Icatú com acesso à rodovia PA-151.

\section{A morfologia em foco}

\subsection{Forma}

Na Análise do Parâmetro Forma foram consideradas as características referentes ao tecido urbano (vias, lotes, quadras), Infraestrutura (água, eletricidade, telefonia, resíduos) e usos institucionais/ equipamentos públicos (escola e posto de saúde). O quadro 2 a seguir sintetiza a condição de cada uma das vilas estudadas.

Quadro 2 - Análise do Parâmetro da Forma

\begin{tabular}{|c|c|c|c|c|c|c|c|c|}
\hline Forma & & Água & Energia Elétrica & Telefonid & Residuos & Escola (nivel) & Posto de saúde & Tipo de tecido \\
\hline \multirow{4}{*}{$\begin{array}{c}\text { Ocupaçăo após } \\
1960\end{array}$} & Sucuriju & M & $\infty$ & Nä & c & D & Naัo & Linear-rodovia \\
\hline & Ateua Grande & A & $\infty$ & Não & c & Pré/F1 & Năo & Linear-rodovia \\
\hline & Olho D'água & A & $\infty$ & sim & c & EJA/F1 E F2 & sim & Grelha \\
\hline & Santa Maria & P & $\infty$ & Năo & c & ELA/F1 & N5้อ & Grelha \\
\hline \multirow{4}{*}{$\begin{array}{l}\text { Ocupaçăo } \\
\text { Tradicional }\end{array}$} & Furtados & p & CA & Sim & a & $F 1$ & Năo & Linear-rio \\
\hline & Mutuacá de babxo & P & $C A$ & Sim & a & $F_{1}$ & $\begin{array}{l}\text { Sim } \\
\text { (des a tivado) }\end{array}$ & Linear - rio \\
\hline & Cantanzal & p & $\infty$ & N3ิ。 & a & D & Nรั० & Malha aberta \\
\hline & Icatú & A & $\infty$ & Nฐ̃ & a & F1 & sim & Malha aberta \\
\hline
\end{tabular}

As vilas Furtados e Mutuacá de Baixo são ribeirinhas, localizadas na várzea do rio Tocantins. Para ambas o rio é a principal forma de acesso e meio de locomoção, é fonte de renda e alimentação (pesca de subsistência) e local de convívio. Enquanto as vilas de Cantanzal e Icatú estão em terra firme e têm o ramal da rodovia como principal acesso para as comunidades. Após a implantação das políticas de integração nacional por meio das rodovias, ocorreu uma transição para a mobilidade terrestre pela facilidade de acesso, e menor tempo de deslocamento, aos centros urbanos mais próximos. Icatú é um exemplo dessa transição, onde as crianças da comunidade se deslocavam para a escola de barco, mas com a construção dos ramais de acesso à rodovia, e a implantação de escolas nas margens da PA-151, o transporte escolar fluvial foi abandonado. Tal mudança facilitou a operação das políticas federais que previam o transporte escolar rodoviário. 
Nas vilas ribeirinhas, o rio é a via principal. Todo o assentamento ocupa terrenos que são alagáveis, e as edificações pertencentes à mesma família são conectadas por estivas ${ }^{4}$ ou por caminhos terrestres, quando possível. Nas vilas localizadas em terra firme, as vias terrestres conectam os pequenos conjuntos de residências ao centro da Comunidade. Enquanto nas vilas tradicionais em terra firme os ramais de estradas passaram a estruturar a mobilidade, nas vilas implantadas após 1960 as rodovias assumiram este papel.

O parcelamento da terra em lotes individualizados também é uma característica marcante das vilas implantadas após 1960, representando em si a individualização, a propriedade privada e a abertura para especulação imobiliária; enquanto nas vilas tradicionais, as edificações compartilham um território apropriado coletivamente. A configuração das casas segue dois padrões: A) podem ser localizadas dentro das áreas de trabalho/cultivo, geralmente próximas à vila para viabilizar o uso das infraestruturas, B) podem estar concentradas dentro da vila. O padrão de configuração " $A$ " é identificado nas vilas ribeirinhas, já o "B" foi notado nas vilas em terra firme. Não existe parcelamento na área central das vilas tradicionais, mas há individualização das áreas de trabalho/cultivo para cada família. Nestas vilas, o extrativismo do açaí tornou-se a principal fonte de renda para os que vivem às margens do rio, enquanto a agricultura familiar é o sustento daqueles que residem na terra firme.

Em Icatú e Cantanzal a individualização da terra ocorre apenas nas áreas de trabalho/cultivo, geralmente distantes do centro da comunidade, onde as residências estão distribuídas sem delimitação de lote. Esta individualização das áreas de trabalho/cultivo é fundamental para a manutenção e sobrevivência da família que depende do extrativismo ou da agricultura. Essa "demarcação de lotes para produção" tornou-se um imperativo para que os agricultores familiares consigam crédito agrícola perante as instituições governamentais (mediante a posse de garantias reais), mas ela não se materializa, na maioria das vezes, no espaço através de cercas e muros.

No caso das vilas implantadas após 1960, há clara demarcação de lotes e a quantidade de cercas e muros indica a intensidade da disseminação da propriedade privada nas vilas. Por

\footnotetext{
${ }^{4}$ Neste caso trata-se de pontes de madeira sobre estacas, que dão acesso às palafitas nas áreas alagadas ou alagáveis.
} 
exemplo Sucuriju possui a menor quantidade de cercas e muros, o que torna a sua ambiência mais semelhante a uma comunidade tradicional, se comparada com Olho D'água, onde as cercas e muros tornam a configuração da vila semelhante à periferia de uma pequena cidade.

A existência de lote ou de agrupamentos de edificações não significa necessariamente a existência de quadras, e quando estas existem são outra característica das vilas implantadas após 1960, que indica o quanto as comunidades rurais absorveram e reproduziram em seu espaço padrões espaciais mais urbanos do que rurais.

Nas vilas tradicionais o mais próximo que se chega de uma quadra é a organização do centro da vila, onde as edificações estão dispostas no entorno de uma área comum, porém não é possível definir essa área como uma quadra, pois não há demarcação de lote. Nas vilas implantadas após 1960 a existência da quadra não é característica essencial, pois existem as vilas de malha linear onde a demarcação de lotes não gera quadras, e as vilas de malha fechada, onde a demarcação de lotes e a organização das vias geram quadras e permitem a expansão do tecido, como ocorreu no caso de Olho D'água.

Certos usos do solo e sua respectiva configuração espacial podem revelar características marcadamente tradicionais como a organização dos centros de comunidade que normalmente são compostos por usos coletivos (campo de futebol e barracão) e usos institucionais (educação, saúde e religioso).

Nas vilas tradicionais o uso exclusivamente comercial não é frequente, o uso misto (residência e comércio) de pequeno porte, em que a edificação residencial possui um cômodo adaptado para servir de pequena loja de conveniência é o mais comum. Nas vilas implantadas após 1960 a coexistência dos arranjos observados em vilas tradicionais com usos exclusivamente comerciais e usos mistos de pequeno porte, indica maior intensidade de provisão de serviços que normalmente são associados à urbanização. Usos comerciais de menor porte, tais como loja de conveniência, borracharia, pequenas confeç̧ões (Comércio I) são o estágio mais básico; a existência de padarias, açougue, peixaria (Comércio II) e serviços profissionais (cabeleireiro, restaurantes) em estabelecimentos de médio porte que promovem maior urbanidade (interação entre pessoas), enquanto a ocorrência de estabelecimentos comerciais de grande porte, tais como supermercado, farmácia, loja de móveis, loja de materiais de construção, informática (Comércio III), articulada à ocorrência de usos institucionais ao maior 
porte (escolas de ensino fundamental completo e posto de saúde) transforma a vila rural em uma centralidade municipal, destacando as comunidades com vida social mais intensa, que também sofreram maior influência da concepção do INCRA. A provisão de infraestrutura por parte dos governos municipais, estaduais ou federais é fator de impacto na qualidade de vida das comunidades com influência na difusão de usos e estratégias de ocupação mais urbanas. A figura 3 reúne um conjunto de croquis que sintetizam o parâmetro forma.

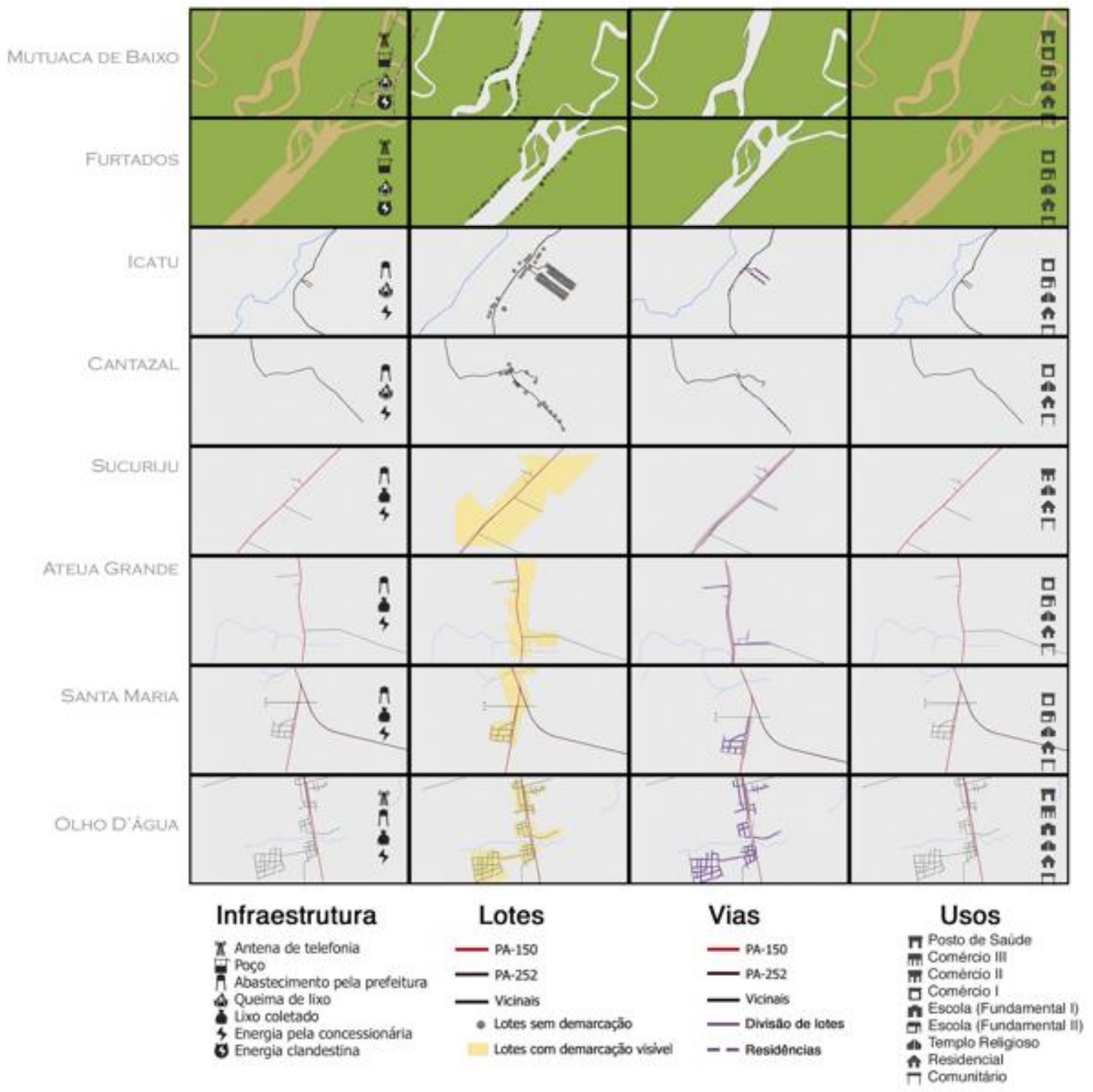

Figura 3 - Croquis de análise do parâmetro forma.

Elaboração: Autoras, a partir de pesquisas de campo realizadas entre 2017 e 2019 e de registros do Google Earth. 
As vilas tradicionais ribeirinhas são as que possuem menor provisão de infraestrutura e menor ocorrência de serviços municipais; vilas tradicionais em terra firme possuem provisão intermediária de infraestrutura, pois sua localização ao longo de vicinais permite que os governos municipais estendam os serviços de abastecimento de água e energia elétrica com maior facilidade. Vilas localizadas às margens de rodovias são as que possuem a maior quantidade de infraestruturas e serviços públicos de mais fácil acesso (nas rodovias), apesar das longas distâncias a serem percorridas desde os pontos mais distantes do assentamento.

Conclui-se que no Parâmetro Forma: (1) a demarcação visual de lotes nos centros das vilas, ou a prática de apropriação comum da terra, é o que melhor permite discriminar os tipos "após 1960" dos "tradicionais" , (2) enquanto nas áreas de trabalho/cultivo a individualização é induzida nas duas tipologias pelas políticas públicas e reforçada pelo sustento do núcleo familiar, e (3) que há maior dificuldade de acesso aos serviços públicos, principalmente quanto à oferta de energia elétrica, coleta e disposição de resíduos ou transporte por parte dos municípios nas vilas tradicionais.

\subsection{Escala}

A análise do Parâmetro Escala foi baseada na relação de lotes/quadras/usos, na composição das centralidades (centro das vilas), na configuração das áreas de cultivo, na relação das centralidades com as áreas residenciais e, ainda, se ocorre a formação de centralidades secundárias. O quadro 3 caracteriza a configuração de cada uma das comunidades estudadas. No bloco das vilas implantadas após 1960, observa-se que a área central corresponde à ocupação às margens da rodovia nas vilas Sucuriju, Ateua Grande e Olho D'Água. Na primeira, a centralidade linear é composta por uma área comunitária (barracão e campo de futebol) conjugada a uma igreja e um conjunto de restaurantes, dentre os quais destaca-se uma churrascaria de médio porte, além destes, os estabelecimentos comerciais de Sucuriju são pequenos e voltados para o atendimento simultâneo interno (habitantes) e externo (pessoas em trânsito) à vila. Na segunda, a centralidade corresponde ao ponto de conexão da rodovia com uma vicinal e é marcada pela concentração de estabelecimentos comerciais, áreas comunitárias (barracão e campo de futebol) e escola. Os demais estabelecimentos são 
pequenos e locais (bares e mercadinhos voltados para o atendimento das necessidades internas à vila), dentre os quais destaca-se a borracharia, que atende público externo.

Quadro 3 - Análise do Parâmetro Escala

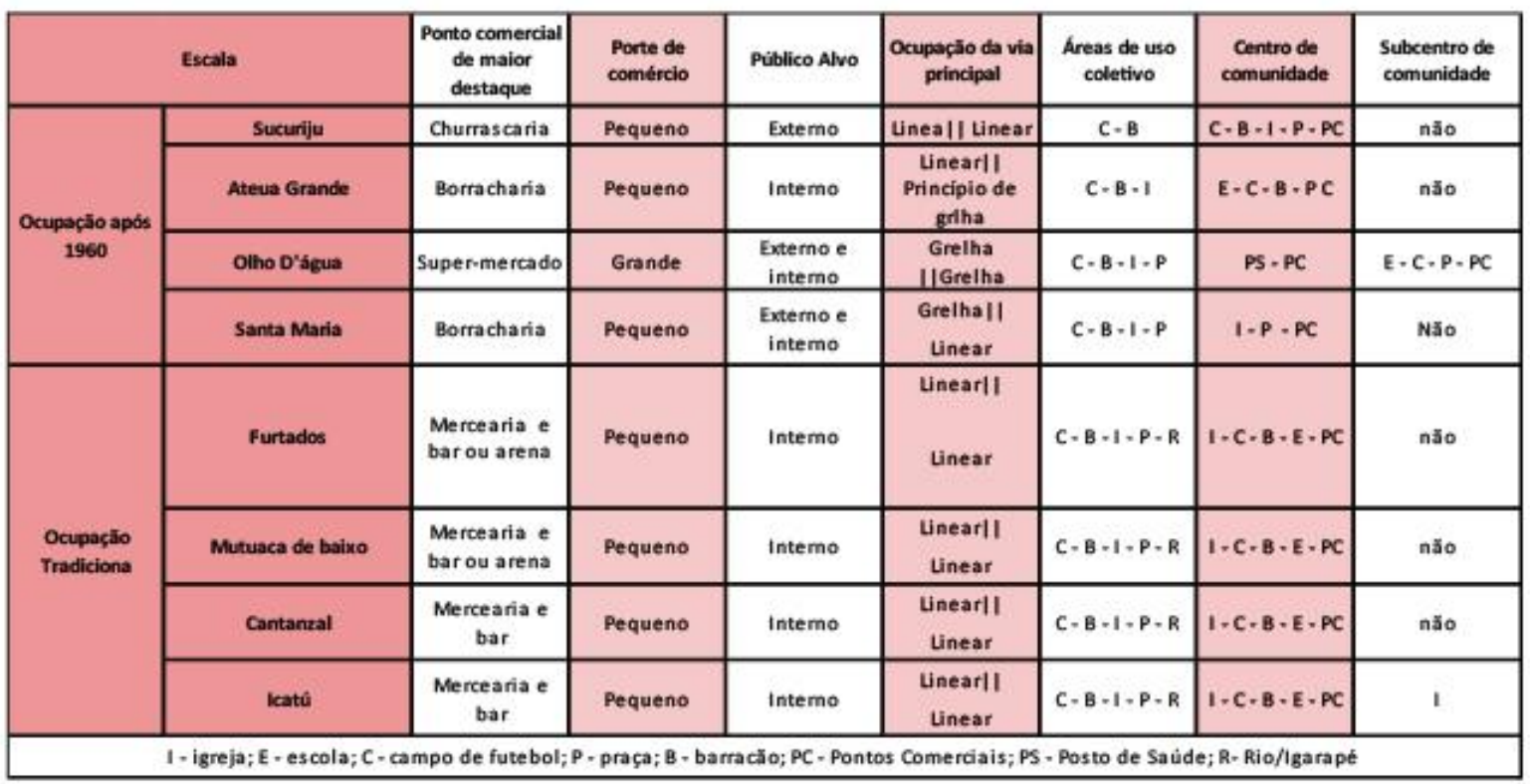

A vila Olho D'água destaca-se pelo seu tamanho, e por contar com centro principal e dois subcentros. O centro principal é formado por posto de saúde circundado por diversos estabelecimentos de comércio e serviço de pequeno porte, como açougue e bares, além de supermercado e loja de móveis. Os subcentros são formados pela escola e pela igreja respectivamente, acompanhados de área comunitária (campo de futebol e praça), à semelhança dos centros das vilas menores da PA-150. Olho D'água atende as demandas de sua população, de quem trafega na rodovia e de comunidades do entorno. A Vila Olho D'água conta com áreas cultivadas (roças) no seu interior, inseridas na área de expansão do tecido ocupado, quando o mais comum é que as áreas de cultivo estejam organizadas fora das comunidades, áreas afastadas da rodovia, subdivididas em lotes rurais individualizados ou, mais raramente, de produção coletiva.

A Vila Santa Maria conta com uma ocupação em grelha em uma das margens da rodovia, e distingue-se das demais por manter o centro da vila distante da rodovia PA-150, definida pela presença da escola e por igrejas adjacentes à áreas comunitárias onde a população introduziu cruzeiro e mobiliários não-fixos (bancos) emulando praças. Os estabelecimentos comerciais da vila são pequenos e voltados principalmente ao atendimento da demanda local, à exceção 
da borracharia, por força de sua natureza, voltada também ao público em trânsito. Um fato que se sobressai sobre a vila (relatado pelo presidente da associação de moradores em pesquisa de campo realizada em 2018) é o seu potencial regional desperdiçado, devido à falhas administrativas (tanto da associação de moradores quanto do município), pois a vila possuía uma micro beneficiadora de farinha com capacidade para beneficiar mandioca de diversas comunidades do entorno, que foi desativada por falta de maquinário.

Nas vilas tradicionais observa-se uma constante morfológica: todas as comunidades estudadas situam-se nas margens de rio ou vicinais, apresentam centros compostos de praça, campo de futebol, igreja e barracão e por usos institucionais, quando existem. Todas as comunidades também possuem estabelecimentos comerciais pequenos, dedicados preferencialmente para o atendimento interno, havendo possibilidade de suporte às vilas mais próximas (mercearias e bares).

Somente em Icatú há um subcentro, devido à influência de uma igreja evangélica. Este fato aponta para uma conclusão importante: nas vilas tradicionais os subcentros são organizados através de um uso coletivo/cultural/religioso, enquanto que nas vilas implantadas após 1960 os subcentros são induzidos por usos institucionais (escola, equipamento de saúde).

Nas vilas tradicionais localizadas na várzea, observa-se maior conexão entre as residências e as áreas de cultivo, elas formam configurações relativamente grandes e dispersas, com baixa densidade demográfica. Nas vilas tradicionais localizadas na terra firme, as áreas de trabalho/cultivo são distantes das residências, que por sua vez são próximas ao centro da comunidade, sem demarcação definida de parcelamento. Icatú é a única das vilas estudadas que possui uma área residencial mais compacta devido à implantação de projeto habitacional genérico da Companhia de Habitação do Estado do Pará (COHAB), de configuração semelhante a de empreendimentos construídos nas cidades, que provocou a descaracterização da ocupação tradicional. 


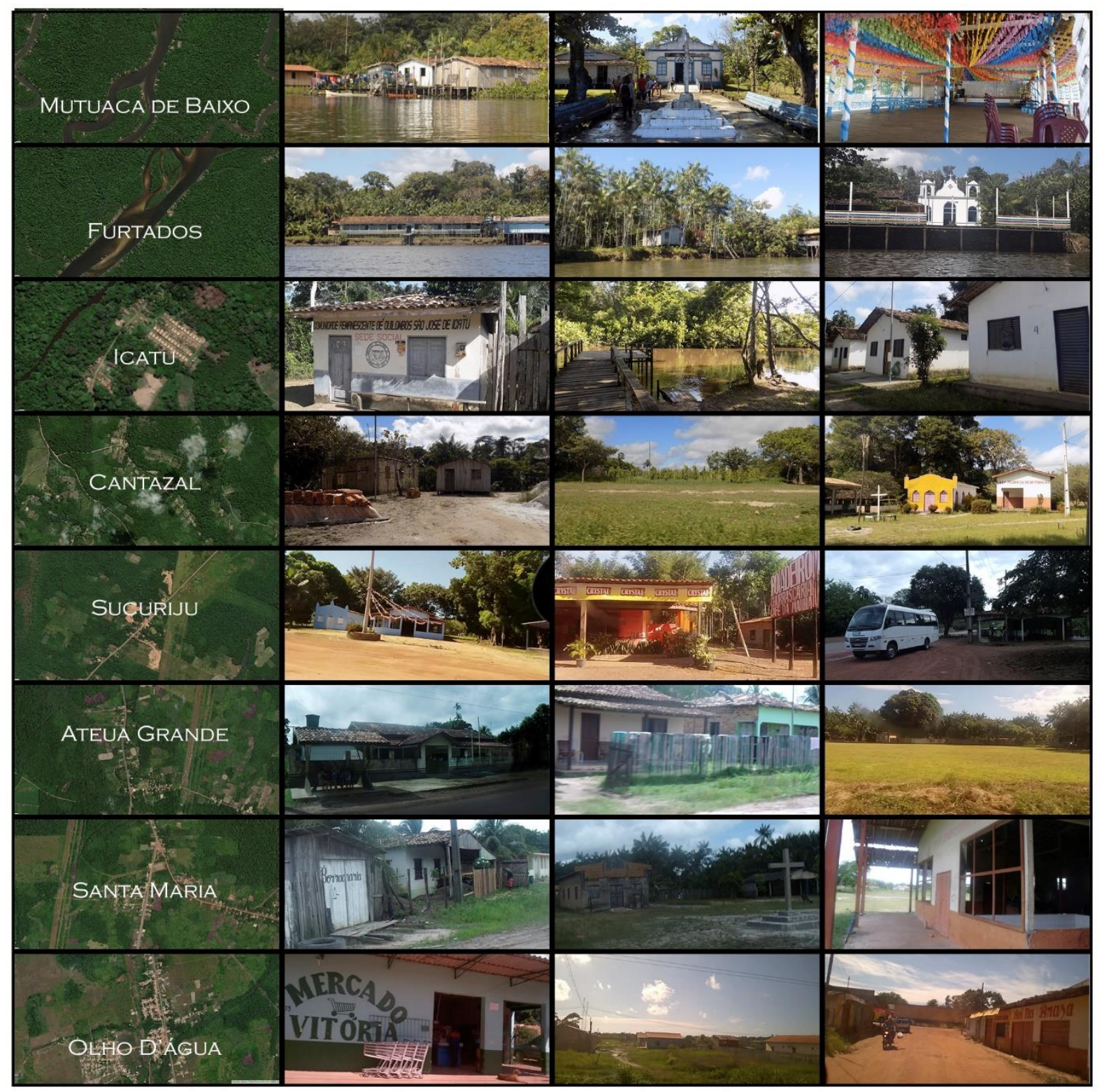

Figura 4 - Imagens das Vilas analisadas. Fonte: Acervo Próprio, a partir de pesquisas de campo realizadas entre 2017 e 2019.

Conclui-se que a composição dos centros das vilas, tanto tradicionais quanto pós-1960, segue o padrão de composição - igreja/campo de futebol/barracão/praça, variando apenas na vila Olho D'água que pode ser considerada uma vila que exerce centralidade municipal. Da amostra desta pesquisa, essa foi a única vila que sofreu intervenção direta do INCRA, e que melhor expressa a importância dos usos institucionais para a consolidação de centralidade, em detrimento dos usos coletivos socioculturais.

O uso comercial também se distingue, na vila tradicional os estabelecimentos comerciais atendem às necessidades de sua população, enquanto nas vilas implantadas após 1960 
podem atender demanda interna e externa, aproveitando o acesso a partir da rodovia, a exemplo das borracharias.

\subsection{Tempo}

O Quadro 4 oferece uma síntese do relacionamento entre tipos de ocupação, políticas públicas e ação de agentes sociais.

Quadro 4 - Análise do Parâmetro Tempo. Fonte: pesquisa de campo realizadas entre 2017 e 2019

\begin{tabular}{|c|c|c|c|c|c|}
\hline \multicolumn{2}{|c|}{ Tempo } & \multirow{2}{*}{$\begin{array}{c}\text { Politica Pública da } \\
\text { formação original }\end{array}$} & \multirow{2}{*}{$\begin{array}{c}\begin{array}{c}\text { Agentes da } \\
\text { formaçăo original }\end{array} \\
\begin{array}{c}\text { Migrantes e } \\
\text { população local }\end{array} \\
\end{array}$} & \multirow{2}{*}{$\begin{array}{c}\begin{array}{c}\text { Politica Pública de } \\
\text { modificação recente }\end{array} \\
\end{array}$} & \multirow{2}{*}{$\begin{array}{c}\begin{array}{c}\text { Agente de } \\
\text { modificaçăo } \\
\text { recente }\end{array} \\
-\end{array}$} \\
\hline \multirow{4}{*}{$\begin{array}{c}\text { Ocupação após } \\
1960\end{array}$} & Sucuriju & & & & \\
\hline & Ateua grande & II PND & $\begin{array}{c}\text { Migrantes e } \\
\text { população local }\end{array}$ & - & - \\
\hline & Olho d'àgua & II PND & $\begin{array}{c}\text { Migrantes e } \\
\text { população local/ } \\
\text { INCRA }\end{array}$ & - & Populaçāo local \\
\hline & Santa Maria & II PND & $\begin{array}{c}\text { Migrantes e } \\
\text { populaçăo local } \\
\end{array}$ & - & Populaçăo local \\
\hline \multirow{4}{*}{$\begin{array}{l}\text { Ocupação } \\
\text { Tradicional }\end{array}$} & Furtados & - & População local & $\begin{array}{l}\text { Demarcaç̧o de } \\
\text { assentamento } \\
\text { agroextrativista }\end{array}$ & Governo Federal \\
\hline & $\begin{array}{l}\text { Mutuacá de } \\
\text { Baixo }\end{array}$ & - & Populaçăo local & $\begin{array}{l}\text { Demarcação de } \\
\text { assentamento } \\
\text { agroextrativista }\end{array}$ & Governo Federal \\
\hline & Cantanzal & - & Populaçăo local & - & - \\
\hline & Icatú & - & Populaçăo local & $\begin{array}{c}\text { Título de } \\
\text { reconhecimento } \\
\text { de dominio } \\
\text { coletivo }\end{array}$ & СОНАВ \\
\hline
\end{tabular}

Todas as vilas surgidas após os anos 1960, têm conexão com a implantação da rodovia estadual PA-150, ou seja, surgiram no período de vigência do II Plano de Desenvolvimento Nacional, que estabeleceu polos para a Amazônia e determinou áreas de incentivo à agropecuária, como foi o caso do município de Moju. 
Na década de 1980, o INCRA passou a atuar na região em que hoje se encontra a Vila Olho D'água, visando resolver as tensões sobre a posse de terra entre a comunidade e as áreas vizinhas dedicadas ao agronegócio. Dentre as quatro vilas estudadas, Olho D’água é a que possui mais características técnicas exatamente por ter recebido influência direta de uma agência governamental e, portanto, por decisão de agentes não-locais, sua configuração original e composição de centro são diferentes das demais comunidades estudadas.

Atualmente, a influência das políticas públicas sobre a configuração espacial das vilas rurais localizadas ao longo da PA-150 é pequena, porém é possível observar tendência de alteração significativa em três das quatro vilas aqui estudadas - Santa Maria, Ateua Grande e Olho D’água, por ação dos seus habitantes.

Na Vila Santa Maria, houve ação local direta, da associação de moradores, para sua emancipação. Em Ateua Grande, a disposição de edificações e caminhos de pedestres no entorno de um dos campos de futebol indica tendência da evolução da malha linear para malha em grelha. A existência de duas escolas de ensino básico indica potencial de criação de um subcentro e a apropriação de pequenos cursos d'água como balneário, à beira da rodovia (com acesso mediante pagamento), revela exploração econômica para turismo e lazer. $\mathrm{Na}$ Vila Olho D'água a própria população está expandindo o tecido viário - não há ação de políticas ou programas habitacionais na vila, gerando três novas áreas de expansão. Todas essas modificações ocorreram por iniciativa de agentes locais.

As vilas tradicionais surgiram por iniciativa da população local e sua forma original é resultante da tomada de decisão e da cultura de agentes locais, contudo, após a introdução das rodovias na Amazônia pelas políticas de integração nacional, vilas tradicionais localizadas na terra firme, como é o caso de Cantanzal e Icatú, tornaram-se dependentes do meio de locomoção terrestre, pela possibilidade de rápido acesso às sedes municipais. Os ramais e as vicinais são eixos de expansão da ocupação nas comunidades tradicionais localizadas em terra firme.

As vilas estudadas, com exceção de Cantanzal, também foram alvo de decisões tomadas por agentes não-locais, quando houve a delimitação e demarcação dos Assentamentos Rurais de proteção às comunidades tradicionais ou extrativistas que hoje as contêm. Todavia, esta ação pública não alterou o modo como as comunidades se organizam, e protegeu seus modos de 
vida. Porém, quando São José de Icatú demandou moradia ao poder público, recebeu um conjunto habitacional com organização espacial que alterou a configuração tradicional e aspectos da vida cotidiana.

Observa-se, portanto, uma inversão de processos. Enquanto nas vilas implantadas após 1960 a gênese e formação deveu-se a agentes não-locais, as alterações recentes são resultado da ação de agentes locais por insuficiência da ação governamental, baseada em repertório tradicional, por outro lado, a gênese vernácula das comunidades tradicionais, baseada na sua herança cultural, começa a sofrer alterações, fruto da chegada de políticas públicas, por meio de ação técnica não informada sobre a espacialidade do modo de vida dessas comunidades e a disseminação de soluções espaciais copiadas das cidades nas comunidades tradicionais.

\section{Considerações finais}

A partir das análises realizadas, o quadro 5 resume as características mais marcantes dos padrões de ocupação estudados.

Quadro 5 - Quadro síntese das características dos tipos morfológicos.

\begin{tabular}{|c|c|}
\hline Ocupaçåo após 1960 & Ocupaçåo Tradicional \\
\hline tecido linear ou grelha & Tecido linear aberto \\
\hline $\begin{array}{l}\text { serviços públicos individualizados (água, luz, telefonia, } \\
\text { coleta de lixo) }\end{array}$ & Usos comunitários de infraestrutura \\
\hline $\begin{array}{l}\text { Elementos fisicos (muros, cercas ou estacas) de } \\
\text { demarcaçăo de lote }\end{array}$ & $\begin{array}{l}\text { Sem elementos fisicos convencionais de demarcação de } \\
\text { lote }\end{array}$ \\
\hline $\begin{array}{l}\text { Equipamento público como ponto focal do centro de } \\
\text { comunidade }\end{array}$ & $\begin{array}{l}\text { Centros formados no entorno da relação } \\
\text { igreja/praşa/barracão associado a equipamentos públicos e } \\
\text { de uso coletivo }\end{array}$ \\
\hline $\begin{array}{l}\text { Pelo menos um estabelecimento comercial é voltado } \\
\text { majoritariamente ao público externo }\end{array}$ & $\begin{array}{l}\text { Estabelecimentos comerciais voltados para o público } \\
\text { interno }\end{array}$ \\
\hline Áreas residenciais aglutinadas & $\begin{array}{l}\text { Área residências dispersas porém próximas aos centros de } \\
\text { comunidade }\end{array}$ \\
\hline Área de cultivo fora do perímetro da vila & Áreas de trabalho/cultivo demarcadas \\
\hline $\begin{array}{l}\text { Formação por ação de agentes locais sob influência de } \\
\text { decisões e orientações técnicas de agentes externos após } \\
\text { os anos } 1960 \text {. }\end{array}$ & $\begin{array}{l}\text { Formaçăo vernacular, o isolamento manteve comunidades } \\
\text { sem influência de políticas públicas até o século XXI. }\end{array}$ \\
\hline
\end{tabular}

Elaboração: Autoras 
A análise temporal revela que os dois tipos se distinguem pela ação de políticas públicas, se existem ou não e quando acontecem. Nas vilas de após 1960, formadas em consequência da política federal de colonização da região, houve uma mescla de iniciativa da população atraída pela migração induzida pelas ações de políticas públicas de colonização agrária com o que já era produzido tradicionalmente. Nos tipos tradicionais, a cultura e ação direta da população local se destaca na sua formação; merece destaque o amparo recente das políticas de caráter socioambiental que permitiram a criação de assentamentos especiais, para proteção de populações tradicionais após a Constituição de 1988.

Contudo, as intervenções nas vilas tradicionais são inadequadas e baseadas em sistemas construtivos e soluções de infraestrutura importadas das cidades, enquanto as políticas de financiamento estão induzindo uma mudança na organização do território, a partir do cercamento e individualização de áreas de trabalho/ cultivo, modificando o relacionamento entre as pessoas, e destas com o bioma. Há risco de descaracterização, exclusão social (por desterritorialização) e degradação ambiental (sobretudo, por exaustão dos recursos primários e da biodiversidade que sustentam estas comunidades), e reedição de processos de colonização anteriores via imposição de valor de troca ao valor de uso das terras usadas para produção. Atualmente, o tipo morfológico implantado após 1960, se constitui em um híbrido, que surgiu pela influência das técnicas de urbanização rural na década de 1970, mas por carência de continuidade de ação oficial, assume o tipo tradicional como referência para expansão, reconhecendo o saber local, ao mesmo tempo em que busca referência nas periferias das cidades, - que por sua vez copiam as metrópoles, evidenciando uma carência de níveis de diferenciação para a política urbana brasileira, visto que é regido pela apropriação individual da terra para moradia e para produção.

A falta de estudos sobre o impacto da provisão de equipamentos, serviços e infraestrutura no contexto rural de municípios da Amazônia brasileira reduz a correspondência entre organização espacial e modos de vida. As políticas são homogeneizadoras, e precipitam o apagamento de parâmetros tradicionais que testaram os limites do meio físico por séculos, e induzem híbridos baseados na alienação socioambiental e mercantilização da terra. As comunidades desejam melhorias, e esperam acesso a políticas públicas, serviços e 
infraestrutura, sem que o preço a ser pago seja a alteração do seu meio de produção ou de sua organização cultural.

Neste sentido, esta contribuição procura alertar os diversos níveis governamentais sobre a necessidade de ampliar a investigação interdisciplinar e multiescalar nesses territórios, visando entender os espaços híbridos e suas especificidades de modo que as intervenções necessárias aconteçam, sem que se tornem instrumento de manutenção da incapacidade histórica de diálogo com a população tradicional e camponesa. A provisão de melhores condições de acesso a equipamentos e infraestruturas nas vilas não deve desencadear sua descaracterização. O apelo simbólico dos muros e das estruturas físicas é forte e, quando associado à solução da necessidade histórica de atendimento das comunidades, acaba por deixar em segundo plano a discussão sobre a adequação das soluções. Espera-se que esta análise morfológica ofereça pistas seguras sobre como a modelagem do espaço responde aos agentes sociais e diretrizes oficiais, e inspire o aprofundamento do debate sobre a preparação necessária para a intervenção e regulação do espaço em vilas rurais, que dialoguem com seus espaços e respondam às demandas mais antigas de sua população por cidadania.

Para além das questões morfológicas, é necessário que outros estudos sejam desenvolvidos, para ampliação do entendimento da vida cotidiana (tais como estudos sobre relações econômicas, uso de tecnologias apropriadas socioambientalmente, solidariedade social ou fatores que promovem urbanidade), das práticas de produção e geração de renda, de educação e custo dos serviços, para que as ações públicas possam promover acoplamentos de conhecimento técnico ao conhecimento local (de tecnologias sociais sobre o como aperfeiçoar velhas práticas), ao invés de induzir rupturas. Toda a cautela é necessária quando se trata da ocupação humana em áreas ambientalmente frágeis, como as várzeas, e onde se desmata uma das últimas florestas tropicais do planeta.

\section{Referências Bibliográficas}

AGUIAR, Douglas. Urbanidade e a qualidade da cidade. In: HOLANDA, Frederico de; NETTO, Vinicius M. (Orgs.). Urbanidades. Rio de Janeiro: Folio Digital: Letra e Imagem, 2012. p. 61-80.

BAENA, A. L. M. (1969). Compêndio das eras da província do Pará. Belém: Universidade Federal do Pará.

CAMARGO, J. G. da C. (1973). Urbanismo rural. Brasília: Ministério da Agricultura, INCRA.

CARDOSO, A. C. D., \& LIMA, J. J. (2006). Tipologias e padrões de ocupação urbana na Amazônia Oriental: para que e para quem? In O rural e o urban na Amazônia (pp. 55-93). Ed. da UFPA. 
CHAMBOULEYRON, R. (2010). Povoamento, ocupação e agricultura na Amazônia colonial (1640-1706).Belém, PA: Açai.

CORRÊA, R. L. (1988) A periodização da rede urbana na Amazônia. Revista Brasileira de Geografia, Rio de Janeiro. $49(03), 39-68$.

COSTA, F. A. (2020). Mudança estrutural na economia agrária da Amazônia: uma avaliação inicial usando os censos agropecuários (1995, 2006 e 2017). Boletim Regional, Urbano e Ambiental. Brasília, IPEA.

Decreto no 6.040 de 07 de fevereiro de 2007. Política Nacional de Desenvolvimento Sustentável dos Povos e Comunidades Tradicionais. Brasília: DF, Brasil.

Decreto-Lei no 311, de 2 de março de 1938. Dispõe sobre a divisão territorial no país e dá outras providências. Rio de Janeiro, DF, Brasil.

HÉBETTE, J.; ACEVEDO, R. (1979) Colonização para quem? Belém: Falangola Offset/Ufpa/naea. 173 p.

HÉBETTE, J., ALVES, J. M. \& QUINTELA, R. Sa S. (2002) Parentesco, vizinhança e organização profissional na formação da frente pioneira amazônica. In: HÉBETTE, J. (Org.). Cruzando a fronteira: 30 anos de estudo do campesinato na Amazônia. (Vol. 4, pp. 101-119).

HECKENBERGER, M. J., RUSSELL, J. C., FAUSTO, C., TONEY, J. R., SCHMIDT, M. J., PEREIRA, E., FRANCHETTO, B., \& KUIKURO, A. (2008). Pre-Columbian Urbanism, Anthropogenic Landscapes, and the Future of the Amazon. Science, 321(5893), 1214 - 1217. 10.1126/science.1159769

IBGE- Instituto Brasileiro De Geografia E Estatística (2012). Censo Brasileiro de 2010. Rio de Janeiro: IBGE.

IBGE- Instituto Brasileiro De Geografia E Estatística. (2014). Noções básicas de cartografia. Disponível em: http://www.ibge.gov.br/home/geociencias/cartografia/manual_nocoes/elementos_representacao.html. Acesso em: 18 dez. 2014.

INCRA (1971). Projeto integrado de colonização Altamira - 1. [Brasília]: INCRA

LARKHAM, P. J. (2019). Agents and Agency in the Urban Landscape. In: OLIVEIRA, V. (ed.). J.W.R. Whitehand and the Historico-geographical Approach to Urban Morphology (Cap. 4, p. 67-90). Cham: Springer.

MALHEIRO, B. \& TRINDADE JÚNIOR, S. C. (2010) Entre Rios, Rodovias e Grandes Projetos: Mudanças e Permanências em realidades urbanas do Baixo Tocantins (Pará). História.

MARIN, R. Povoamentos e sociedades entre os Rios Gurupi e Moju no Pará dos séculos XVIII e XIX. In: MONTEIRO, M. de A., COELHO, M. C. N. \& BARBOSA, E. J. da S. (2009). Atlas Socioambiental: Municípios de Tomé-Açu, Aurora do Pará, Ipixuna do Pará, Paragominas e Ulianópolis (pp. 33-44). Belém: NAEA.

MIRANDA, E.. Área entre os Rios Gurupi e Moju no contexto da formação territorial da Amazônia - 1616 a 1753. In: MONTEIRO, M. de A., COELHO, M. C. N. \& BARBOSA, E. J. da S. (2009). Atlas Socioambiental: Municípios de Tomé-Açu, Aurora do Pará, Ipixuna do Pará, Paragominas e Ulianópolis (pp. 29-32). Belém: NAEA.

MONTE-MÓR, R. (1994). Urbanização extensiva e lógicas de povoamento: um olhar ambiental. In: SANTOS, M. et al. (Org.). Território, globalização e fragmentação. São Paulo, Hucitec.

MOUDON, A. V. (1997). Urban morphology as an emerging interdisciplinary field. Urban Morphology, Porto, 1 , 3-10.

NETTO, Vinicius M. A urbanidade como devir do urbano. In: HOLANDA, Frederico de; NETTO, Vinicius M. (Orgs.). Urbanidades. Rio de Janeiro: Folio Digital: Letra e Imagem, 2012. p. 33-60.

PORTO-GONÇALVES, C. W. (2005) Amazônia, amazônias (2.ed) São Paulo: contexto.

RUA, J (2015). O preço da terra e os megaprojetos como marcantes urbanidades no rural na fase atual de organização do espaço geográfico. In: FERREIRA, Alvaro; RUA, João; MATTOS, Regina Célia de (Orgs.). Desafios da metropolização do espaço: modos de viver e pensar o rural na sociedade brasileira. Rio de Janeiro: Consequência, 2015. p. 389-420.

RUA, J. (2006). Urbanidades no rural: o devir de novas territorialidades/urbanities on rural areas: the becoming of new territorialities. Campo-Território: Revista de Geografia Agrária, Uberlândia, 1(1). 
SILVA, Arystides Resende et al. Manejo e Conservação do Solo. In: BELÉM. EMBRAPA. (ed.). Cultura da Mandioca - Apostila. Belém, Pará: Embrapa, (2014). p. 30-46. Disponível em: https://ainfo.cnptia.embrapa.br/digital/bitstream/item/112346/1/Apostila-Mandioca.pdf. Acesso em: 10 jun. 2021.

TAVARES, M. G. da C. (2011). A Amazônia brasileira: formação histórico-territorial e perspectivas para o século XXI. Formação Histórico-territorial e Perspectivas Para O Século XXI, São Paulo, 29, 107-121. Disponível em: www.revistas.usp.br/geousp/article/view/74209/77852. Acesso em: 13 mar. 2016.

WEIMER, G. (2012). Arquitetura Popular Brasileira (2a ed.). São Paulo. Editora WMF Martins Fontes Ltda.

WHITEHAND, J. W. R. (2013) Morfologia urbana Britânica: a tradição Conzeniana. Revista de Morfologia Urbana, Porto, 1,(1), 45-52. Disponível em: http://pnum.fe.up.pt/pt/files/1913/8418/5713/Whitehand 2013.pdf. 